\title{
EVALUASI KESESUAIAN LAHAN DAN POTENSI PRODUKSI TANAMAN MANGGIS (Garcinia mangostana L.) DI KAB.50 KOTA
}

\author{
Juniarti ${ }^{1)}$, Yulnafatmawita ${ }^{1)}$, Sudewi Isminingsih ${ }^{2)}$ \\ 1) urusan Tanah $F$ akultas Pertanian U niversitas Andalas Padang \\ 2) Mahasiswa J urusan Tanah F akultas Pertanian U niversitas Andalas Padang
}

\begin{abstract}
This research discusses the land suitability of mangosteen field in Kab.50 Kota Kota Payakumbuh, predict production potential of mangosteen based on the climate suitability, soil and management its field. Composite soil sample is taken through drilling $0-60 \mathrm{~cm}$ which is carried out on research site. Quantitative model from FAO (1976) is used to evaluate the land suitability. This model combines enviromental data, climate and soil condition (soil physic and chemistry characteristic), so that production potential of field based on climate (Climate Production Potential $=\mathrm{CPP}$ ) can be maesured quantitatively. By entering the real data of plant production, this model can predict the real plant production in a field (Land Production Potential $=$ LPP). Result of this research shows that climate and physical condition of land are very suitability to grow mangosteen, and its level appropriateness is S1 (very suitability). Then, production potential $3-12$ ton/ha/year can be increased to $>15$ ton/ha/year if the management of land is improved.
\end{abstract}

\section{Key Words: Land suitability evaluation, Climatic Production Potential, Land Production Potential}

\section{PENDAHULUAN}

Kebutuhan informasi/data sumber daya lahan untuk perencanaan pembangunan adalah sangat penting. . Sumberdaya lahan merupakan salah satu faktor fisik utama untuk dipertimbangkan dalam perencanaan, penyusunan dan pelaksanaan tata ruang terutama di daratan. Pengalaman dari berbagai pengembangan wilayah banyak menimbulkan masalah fisik yang berakibat buruk kepada kehidupan sosial dan ekonomi masyarakat, sehingga peran data sumberdaya lahan menjadi penting dan harus diperhatikan.

Kabupaten Lima Puluh Kota di Propinsi Sumatera Barat merupakan sentra komoditas hortikultura yang potensial, terutama buah-buahan. Hal ini didukung oleh potensi sumber daya alamnya yang sesuai untuk beberapa komoditas buahbuahan diantaranya manggis. Komoditas manggis mulai berkembang di Kabupaten 50 Kota sejak tahun 1970 di Kecamatan Guguk dan
Payakumbuh. Pada tahun \pm 1974 komoditas manggis ini telah menyebar keseluruh dataran disekitarnya.

Manggis tumbuh dan berkembang baik di daerah dengan ketinggian 4 meter sampai 800 meter diatas permukaan laut dan temperatur $22-32{ }^{\circ} \mathrm{C}$. Berdasarkan kesesuaian agroklimat tersebut maka Kecamatan Guguk dan Payakumbuh di Kabupaten 50 Kota sangat cocok untuk di kembangkan sebagai sentra komoditas manggis.

Untuk mengevaluasi kesesuaian lahan digunakan model kuantitatif dari FAO (1976) yang memadukan data lingkungan, iklim dan kondisi tanah (sifat fisika dan kimia tanah). Setiap data diberi penilaian (rating) tersendiri dan dimasukkan kedalam beberapa rumus matematika sehingga akhirnya didapatkan potensi produksi suatu lahan berdasarkan iklim (Climatic Production Potential = CPP) secara kuantitatif. Dengan memasukkan data produksi tanaman yang sebenarnya model ini akan dapat memprediksi produksi tanaman yang 
tanaman yang sebenarnya dari suatu lahan $($ Land Production Potential $=$ LPP $)$. Adanya program modeling ini, akan lebih memudahkan untuk menyusun program perencanaan oleh pemerintah daerah dan petani di daerah ini. Dengan mengganti beberapa variabel tertentu dari program modeling ini, dapat juga memprediksi hasil tanaman pada daerah lain (Fiantis, 2001).

Tujuan penelitian ini adalah:

1. Untuk menilai tingkat kesesuaian lahan di Kabupaten 50 Kota untuk pengembangan komoditi tanaman manggis

2. Memprediksi potensi produksi tanaman manggis di Kabupaten 50 Kota Propinsi Sumatera Barat sesuai dengan tingkat kesesuaiannya.

\section{BAHAN DAN ETODA}

Penelitian terdiri dari dua tahap yaitu:

1) studi kepustakaan, pengumpulan data primer yaitu data produksi melalui wawancara dengan petani dan data sekunder berupa penelaahan bahanbahan referensi dari laporan yang ada.

2) survey dan pengambilan contoh tanah di lapangan

Pemilihan lokasi pengambilan contoh berdasarkan informasi yang di dapat dari peta topografi, tanah dan iklim daerah yang bersangkutan.. Bahan yang digunakan dalam penelitian ini adalah contoh tanah komposit yang diambil pada lokasi penelitian. Alat yang digunakan dalam pelaksanaan penelitian untuk survey dan pengambilan contoh tanah digunakan alat-alat standar ke lapangan seperti bor tanah, cangkul, parang, pisau lapang, soil tester, GPS (Geographical Positioning Satellite), Munsell Soil Color Chart, kertas label, kartu deskripsi tanah, spidol, kantong plastik, ring sampel serta alat-alat tulis dan peralatan lainnya yang diperlukan selama penelitian serta bahan dan alat untuk analisis tanah selengkapnya .

Sebelum sampel tanah dianalisis, terlebih dahulu sampel tanah dikering- anginkan, sebahagian dihaluskan dan diayak dengan ukuran mesh yang sesuai dengan kebutuhan tanah untuk analisis.

Pengamatan sifat dan ciri tanah meliputi:

1. Analisis C-organik tanah menggunakan metode Walkey and Black (Walkey, 1947 cit Tan, 1996).

2. Analisis $\mathrm{N}$ total tanah dengan metode Kjeldahl (Mulvaney, 1982 cit Page, Miller and Keeney, 1982).

3. Analisis $\mathrm{P}$ tersedia tanah dengan metode Bray II (Olsen and Sommers, 1982 cit Page et al, 1982).

4. Analisis $\mathrm{pH}$ tanah dengan metode Elektrometrik $\mathrm{pH}$ meter elektroda

5. KTK dengan metode pencucian Ammonium Asetat $1 \mathrm{~N} \mathrm{pH} 7$ begitu pula dengan penetapan Kation Basa.

Analisa Penilaian Kesesuaian Lahan Tanaman Manggis (Interpretasi Data)

Dari hasil pengamatan di lapangan dan analisis laboratorium diinterpretasikan berdasarkan kondisi tanahnya di lapangan dengan produksi manggis yang dihasilkan, yaitu dengan membandingkan karakteristik lahan dengan produksi tanaman manggis yang dihasilkan.

Penilaian kesesuaian lahan dilakukan pada tingkat semi detil dengan skala peta 1:50.000. Pada kategori semi detil ini diperlukan data yang terdiri atas:

(1) Data iklim yaitu rata-rata jam penyinaran matahari (n, jam/hari); rata-rata suhu udara maksimum $\left(\mathrm{T}_{\max }{ }^{\circ} \mathrm{C}\right)$, rata-rata suhu udara minimum $\left(\mathrm{T}_{\min }{ }^{\circ} \mathrm{C}\right)$; rata-rata humiditas harian $(\mathrm{RH}$, $\%)$; rata-rata kecepatan angin $(\mathrm{U}$, $\mathrm{ms}^{-1}$ and $\mathrm{m}$ hari $\left.{ }^{-1}\right)$. Total hujan bulanan $(\mathrm{P}, \mathrm{mm})$, dan jumlah hari hujan (RD).

(2) Data lingkungan tanah seperti drainase anah; kedalaman efektif tanah, periode banjir, kemiringan lahan, batu di permukaan (Rock outcrop); atau 
(3) Data karakteristik tanah yaitu KTK, $\mathrm{pH}, \mathrm{N}$ total, $\mathrm{P}_{2} \mathrm{O}_{5}$ tersedia, $\mathrm{K}_{2} \mathrm{O}$ tersedia

\section{Penentuan Potensi Produksi berdasarkan Radiasi Sinar Matahari}

Untuk menduga potensi produksi tanaman manggis berdasarkan radiasi sinar matahari digunakan rumus Pendugaan Potensi Produksi berdaasarkan Radiasi sinar matahari (RPP) (Sys et all, 1991). Untuk menentukan RPP ini dipakai data produksi biomasa bersih yang di dapatkan dengan rumus matematika berikut:

$$
\mathrm{Bn}=\mathrm{Bg}-\mathrm{R}
$$

dimana

$\mathrm{Bn}=$ Produksi biomasa bersih $\left(\mathrm{kg} \mathrm{CH}_{2} \mathrm{Oha}\right.$ 1)

$\mathrm{Bg}=$ Produksi biomasa kotor $\left(\mathrm{kg} \mathrm{CH}_{2} \mathrm{O}\right.$ ha ${ }^{1}$ )

$\mathrm{R}=\operatorname{Respirasi}\left(\mathrm{kg} \mathrm{CH}_{2} \mathrm{O} \mathrm{ha}{ }^{-1}\right)$.

Persamaan (1) dapat juga ditulis dengan menggunakan kecepatan/laju proses produksi biomasa dengan rumus:

dimana

$$
\mathrm{bn}=\mathrm{bg}-\mathrm{r}
$$

bn $=$ kecepatan produksi biomasa bersih ( $\mathrm{kg} \mathrm{CH}_{2} \mathrm{O} \mathrm{ha}^{-1} \mathrm{hr}^{-1}$ )

bg = kecepatan produksi biomasa kotor ( $\mathrm{kg} \mathrm{CH}_{2} \mathrm{O}$ ha $^{-1} \mathrm{hr}^{-1}$ )

$\mathrm{r}=$ kecepatan respirasi $\left(\mathrm{kg} \mathrm{CH}_{2} \mathrm{O} \mathrm{ha}^{-1}\right.$ $\mathrm{hr}^{-1)}$

atau dapat juga di duga dengan kecepatan produksi maksimum dengan rumus:

$$
\mathrm{bnm}=\mathrm{Bgm}-\mathrm{rm}
$$

dimana

bnm $=$ Kecepatan produksi biomasa bersih maksimum $\left(\mathrm{kg} \mathrm{CH}_{2} \mathrm{O} \mathrm{ha}^{-1} \mathrm{hr}^{-1}\right)$

bg = Kecepatan produksi biomasa kotor maksimum $\left(\mathrm{kg} \mathrm{CH}_{2} \mathrm{O} \mathrm{ha}^{-1} \mathrm{hr}^{-1}\right)$

$\mathrm{r} \quad=$ Kecepatan respirasi maksimum ( $\mathrm{kg} \mathrm{CH}_{2} \mathrm{O}$ ha $^{-1} \mathrm{hr}^{-1}$ )

RPP dari suatu tanaman akhirnya dapat dihitung dengan menggunakan rumus berikut :

$$
\mathrm{RPP}=\mathrm{Bn} \times \mathrm{Hi}
$$

$$
\mathrm{RPP}=\frac{0.36 \times \operatorname{bgm} \times \mathrm{KLAI} \times \mathrm{Hi}}{\frac{1}{\mathrm{~L}}+(0.25 \mathrm{ct})}
$$

$\operatorname{bgm}=f x b o+(I-f) x b c$

dimana

$\mathrm{f}=$ fraction of the day time that sky is overcast

bo $=$ Maximum gross biomass production on overcast days

$\mathrm{bc}=$ Maximum gross biomass production on clear days

$\mathrm{Hi}=$ Harvest indeks (indeks panen)

Parameter di atas diperoleh dari data sekunder yaitu data iklim berupa rata-rata jam penyinaran matahari (n, jam/hari), rata-rata suhu udara maksimum $\left(\mathrm{T}_{\max }{ }^{0} \mathrm{C}\right)$, rata-rata suhu udara minimum $\left(\mathrm{T}_{\min }{ }^{0} \mathrm{C}\right)$, rata-rata humiditas harian $(\mathrm{RH}$, $\%)$, rata-rata kecepatan angin $\left(\mathrm{U}, \mathrm{ms}^{-1} \mathrm{dan}\right.$ m hari ${ }^{-1}$ ).

Penentuan Potensi Produksi berdasarkan Iklim

Untuk menduga potensi produksi tanaman manggis berdasarkan iklim digunakan rumus Pendugaan Potensi Produksi berdasarkan Iklim (CPP). Penghitungan CPP dimulai dengan menghitung parameter-parameter dibawah ini (Van Ranst, 1991):

(i) Evapotranspirasi dari tanaman referensi (ETo);

(ii) Evapotranspirasi aero $\left(\mathrm{ET}_{\text {aero }}\right)$

(iii) Evapotranspirasi radiasi (ET rad)

(iv) Evapotranspirasi maximum $\left(\mathrm{ET}_{\max }\right)$

(v) Koefesien tanaman $(\mathrm{kc}=$ crop coefficient)

(vi) Total ketersediaan air (Sa), yaitu jumlah air antara kapasitas lapang dan titik layu permanen;

(vii) Curah hujan-efectif $\left(\mathrm{P}_{\text {eff }}\right)$;

Rumus untuk menghitung CPP adalah $\mathrm{CPP}=\mathrm{RPP}\left[1-\mathrm{ky}\left(1-\mathrm{ET}_{\mathrm{a}}\right) / \mathrm{ET}_{\max }\right]$,

lahan digabung baik melalui 
Dimana

ky adalah faktor respon panen, yaitu sejauh mana iklim mempengaruhi produksi tanaman dan $\mathrm{ET}_{\mathrm{a}}$ adalah evapotranspirasi sebenarnya (actual evapotranspiration).

Penentuan Potensi Produksi berdasarkan Manajemen dan Pengelolaan Lahan

Sedangkan Pendugaan Produksi berdasarkan Manajemen dan pengelolaan lahan selain iklim dan radiasi sinar matahari (LPP) digunakan untuk menghitung potensi produksi tanaman manggis berdasarkan aspek manajemen/pengelolaan tanah, selain mempertimbangkan aspek lingkungan yaitu iklim dan radiasi sinar matahari.

LPP dihitung setelah didapatkan nilai CPP dengan memperhatikan indeks data tanah (Sy) dan indeks pengelolaan lahan (My), dengan rumus:

Dimana

$$
\text { LPP = CPP x My x Sy; }
$$

$\mathrm{My}=\mathrm{Ya} /\left(\mathrm{CPP} \times \mathrm{Sy}_{\mathrm{p}}\right)$,

$\mathrm{Ya}=$ Produksi tanaman di lapangan $(\mathrm{kg} / \mathrm{ha})$;

$S y_{p}=$ indeks tanah yaitu sifat (karakteristik) tanah yang didapatkan dari rumus pendekatan berdasarkan perhitungan Storie Method dan Square Root Method secara parametrik; sedangkan My diperoleh dari tabel yang dikeluarkan FAO tentang rating pengelolaan suatu lahan (Lampiran 6) (Sys et all, 1991).

Pendekatan parametrik dalam evaluasi/penafsiran karakteristik lahan dilakukan dengan memberi angka numerik dari 0 (minimum) s/d 100 (maksimum), untuk setiap karakter/kualitas lahan. Jika suatu karakter lahan dinilai optimal untuk suatu peruntukan yang dimaksud diberi bobot maksimum yaitu 100, jika lahan tersebut tidak favorable diberi nilai minimum. Kemudian untuk keseluruhan evaluasi bobot dari masing-masing karakter penambahan atau penggandaan. Metode yang digunakan dalam prosedur penggandaan untuk evaluasi lahan yaitu:

(a) Storie Method

$$
\mathrm{I}=\mathrm{A} \times \frac{\mathrm{B}}{100} \times \frac{\mathrm{C}}{100} \times \ldots . .
$$

Dimana

$\mathrm{I}=$ indeks lahan,

$\mathrm{A}, \mathrm{B}, \mathrm{C}$ adalah.... /bobot masing-masing karakter/ kualitas lahan

(b) Square Root Method

$$
I=R \min x \sqrt{\frac{A}{100} \times \frac{B}{100} x}
$$

Dimana

$\mathrm{R}$ min = bobot minimum I dan

A, B, C adalah bobot masing-masing karakter lahan

\section{HASIL DAN PEMBAHASAN}

Kabupaten 50 Kota

Daerah kabupaten 50 Kota secara geografis berada pada $00^{\circ} 04^{\prime}-00^{0} 10^{\prime} \mathrm{LS}$ dan $100^{\circ} 27^{\prime}-100^{\circ} 39^{\prime}$ BT dengan luas daerah pertanian sekitar $19.793 \mathrm{Ha}$, dengan luas pertanaman manggis $213 \mathrm{Ha}$ terletak pada daerah dengan topografi datar sampai bergelombang.

Secara agroklimat di Kabupaten 50 Kota tanaman manggis tumbuh pada curah hujan 100 sampai $2500 \mathrm{~mm} / \mathrm{tahun}$ dengan kelembaban $70 \%$ dan temperatur rata-rata $25^{\circ} \mathrm{C}$ sampai $28^{\circ} \mathrm{C}$. Berdasarkan perhitungan dan analisis yang dilakukan terhadap data presipitasi (curah hujan) yang dikumpulkan oleh Berlage (1949), maka diperoleh presipitasi rata-rata tahunan $2238.773 \mathrm{~mm} / \mathrm{tahun}$, dengan jumlah hari hujan rata-rata 15 hari. Data presipitasi dapat dilihat pada Tabel 1 . 
Tabel 1. Rata-rata presipitasi bulanan dan tahunan di Kabupaten 50 Kota 10 tahun terakhir.

\begin{tabular}{|l|c|c|c|}
\hline \multicolumn{1}{|c|}{ Bulan } & $\begin{array}{c}\text { Rata-rata Presipitasi } \\
(\mathrm{mm})\end{array}$ & $\begin{array}{c}\text { Evapotranspirasi } \\
(\mathrm{mm})\end{array}$ & $\begin{array}{c}\text { Surplus air } \\
(\mathrm{mm})\end{array}$ \\
\hline Januari & 266.6818 & 108.2273 & 158.4545 \\
Februari & 204.2727 & 114 & 90.2727 \\
Maret & 210.1818 & 137.3636 & 72.8182 \\
April & 267.8182 & 112.0909 & 155.7273 \\
Mei & 173.3636 & 134.5455 & 38.8181 \\
Juni & 90.95455 & 126.4545 & -35.5 \\
Juli & 161 & 119.2727 & 41.7273 \\
Agustus & 106.9545 & 115.8182 & -8.8637 \\
September & 140.0909 & 114.9091 & 25.1818 \\
Oktober & 190.0909 & 123.5455 & 66.5454 \\
November & 232.5455 & 116 & 116.5455 \\
Desember & 194.8182 & 106.3182 & 88.5 \\
\hline Total & 2238.773 & 1428.546 & 810.2272 \\
\hline
\end{tabular}

Sumber : Stasiun Klimatologi Tanjung Pati, Harau (2005)

Pada Tabel 1. terlihat presipitasi tertinggi terdapat pada bulan April. Selanjutnya dalam grafik neraca air pada Gambar 1. terlihat pada bulan-bulan tersebut presipitasi lebih tinggi daripada evapotranspirasi sehingga dapat digolongkan kedalam regim kelembaban Perudic (presipitasi setiap bulan selalu melebihi evapotranspirasi), dan kondisi ini menyebabkan terjadinya kelebihan air (surplus air). Hal ini jelas terlihat dalam neraca air daerah kabupaten 50 Kota..

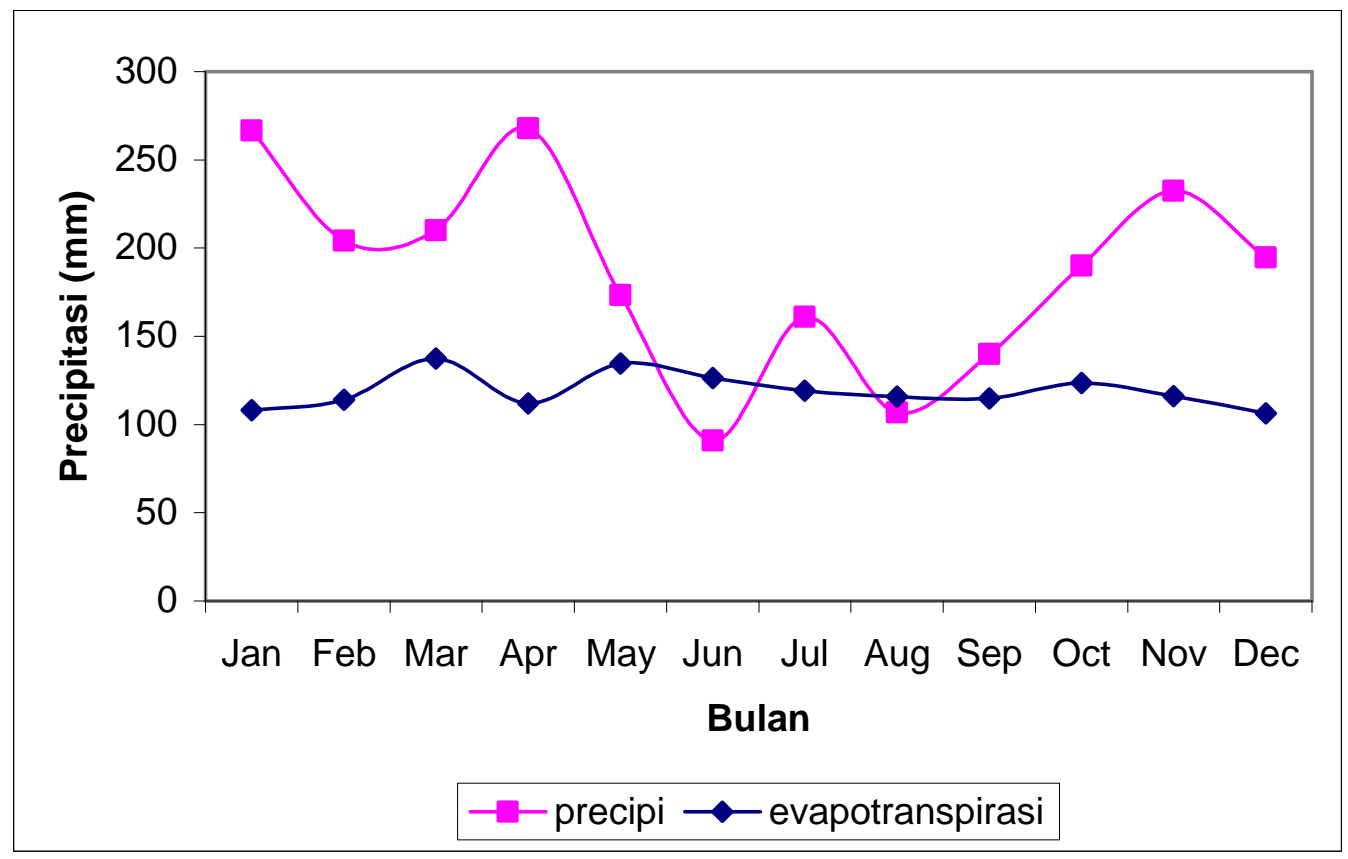

Gambar 1. Neraca air tahunan daerah Kabupaten 50 Kota 
Berdasarkan klasifikasi iklim menurut Schmidt dan Ferguson (1951), tipe hujan di daerah ini termasuk pada daerah tipe iklim A (amat basah) dengan nilai quotien $(\mathrm{Q})$ antara 0 dan $14,33 \%$. Sedangkan menurut klasifikasi Koppen termasuk tipe iklim Af, yaitu tipe iklim tropis atau selalu basah tanpa bulan kering. Suhu udara normal bulan terdingin lebih dari $18^{\circ} \mathrm{C}$, dan suhu bulan terpanas diatas $22^{\circ} \mathrm{C}$. Kondisi iklim tersebut dapat menunjang keberhasilan pertanian, khususnya tanaman Manggis.

Evaluasi Keadaan Iklim untuk Pertumbuhan dan Produksi Manggis di Kab. 50 Kota

Pertumbuhan dan produksi manggis terutama dipengaruhi oleh faktor lingkungan yaitu iklim dan tanah. Faktor iklim sangat berpengaruh terhadap pertumbuhan dan produksi manggis. Unsur-unsur iklim seperti hujan, radiasi, suhu, angin, kelembaban dan tingkat evaporasi potensial menentukan ketersediaan air, energi dan secara langsung mempengaruhi ketersediaan hara bagi tanaman.

Berdasarkan data iklim maka tanah di lokasi penelitian dapat digolongkan kepada lahan yang berpotensi untuk pengembangan tanaman manggis. Potensi air untuk kebutuhan tanaman manggis termasuk sangat cukup, temperatur udara sesuai sehingga ordo kesesuaian lahan berdasarkan data iklim adalah sangat sesuai (S1). Presipitasi pada daerah Kabupaten 50 Kota lebih besar bila dibandingkan dengan potensial evapotranspirasi menurut Papadakis (1970), hal ini dapat dilihat pada Tabel 1, dengan demikian terjadi surplus air walaupun terdapat bulan kering. Dengan curah hujan yang merata ini maka ketersediaan air mencukupi untuk pertumbuhan tanaman manggis. Air merupakan pelarut unsur-unsur hara di dalam tanah, dengan bantuan air unsur hara tersebut menjadi tersedia bagi tanaman. Sebaliknya bila kekurangan air, akar tanaman sukar untuk menyerap unsur hara dari dalam tanah, yang berakibat pada musim kemarau yang berkepanjangan, sehingga akan menyebabkan produksi tanaman menurun (Fiantis, 2001).

Sementara hasil kalkulasi besarnya evapotranspirasi untuk tanaman referensi $\left(\mathrm{ET}_{0}\right)$ dengan menggunakan metoda Radiasi (Dorenbos and Pruitt ,1977) ternyata lebih tinggi bila dibandingkan dengan nilai PET dengan menggunakan metoda radiasi

Tabel 2. Potensial Evapotranspirasi (PET) menurut Papadakis (1970) untuk daerah Kabupaten 50 Kota

\begin{tabular}{lllllcc}
\hline \multicolumn{1}{c}{ Bulan } & $\begin{array}{c}\text { Presipitasi } \\
(\mathrm{mm})\end{array}$ & ea $\mathrm{a}_{\text {tmax }}$ & $\mathrm{ea}_{\text {tmean }}$ & $\mathrm{RH}(\%)$ & $\begin{array}{c}\mathrm{ed}= \\
\left(\begin{array}{c}\text { eatmean*RH } \\
\text { mean }) / 100\end{array}\right.\end{array}$ & $\begin{array}{c}\text { PET }= \\
5.625(\mathrm{eatmax} \\
-\mathrm{ed})(\mathrm{mm})\end{array}$ \\
\hline Januari & 266.68 & 50.05 & 32.87 & 97.49 & 32.04 & 101.27 \\
Februari & 204.27 & 50.87 & 36.05 & 97.75 & 35.24 & 87.91 \\
Maret & 210.18 & 50.95 & 36.82 & 97.70 & 35.97 & 84.26 \\
April & 267.82 & 51.44 & 37.06 & 97.68 & 36.19 & 85.76 \\
Mei & 173.36 & 51.56 & 36.84 & 97.92 & 36.07 & 87.08 \\
Juni & 90.95 & 52.19 & 35.55 & 98.13 & 34.89 & 97.36 \\
Juli & 161 & 51.76 & 35.94 & 98.09 & 35.26 & 92.78 \\
Agustus & 106.95 & 50.93 & 35.84 & 96.91 & 34.73 & 91.08 \\
September & 140.09 & 51.44 & 35.01 & 97.56 & 34.15 & 97.24 \\
Oktober & 190.09 & 51.04 & 34.97 & 97.63 & 3.14 & 95.06 \\
November & 232.55 & 50.44 & 29.88 & 97.48 & 29.12 & 119.93 \\
Desember & 194.82 & 50.21 & 35.42 & 97.68 & 34.60 & 87.83 \\
& & & & & & \\
\hline Total & 2238.77 & 612.88 & 422.25 & 1172.02 & 412.43 & 1127.56 \\
\hline
\end{tabular}


(Papadakis, 1970). Perbedaan ini dikarenakan Papadakis memperhitungkan jumlah presipitasi dan suhu udara rata-rata dan maksimum, sedangkan Dorenbos and Pruit menambahkan beberapa parameter lain seperti kelembaban udara relatif, kecepatan angin, lamanya penyinaran matahari, panjang hari dan radiasi. Hasil penelitian menunjukkan bahwa besarnya evapotranspirasi untuk tanaman referensi manggis $\left(\mathrm{ET}_{0}\right)$ harian dengan mengunakan metoda radiasi (Dorenbos and Pruit, 1977) berkisar antara $0.39-0.7 \mathrm{~mm}$ dan bulanan antara $10.85-21.95 \mathrm{~mm}$ lebih tinggi bila dibandingkan dengan nilai PET dengan menggunakan metoda radiasi (Papadakis, 1970).

Selanjutnya dari hasil kalkulasi parameter iklim yang terdiri dari presipitasi suhu udara maksimum, suhu udara minimum dan suhu udara rata-rata, lamanya penyinaran matahari dan panjang hari, kecepatan angin dan kelembaban udara, maka potensi produksi tanaman manggis berdasarkan iklim adalah termasuk kelas sesuai (S), terlihat dari hasil perhitungan CPP yaitu potensi produksi berdasarkan curah hujan dan LPP yaitu potensi produksi manggis berdasarkan iklim dan tanah serta pengelolaannya untuk tanaman manggis dapat dilihat pada Tabel 3 dan 4.

Dari Tabel 3 dan 4 terlihat bahwa lahan di lokasi penelitian daerah Kab.50 Kota sesuai bila dikembangkan untuk tanaman manggis. Dengan membandingkan data dari kondisi lingkungan agroklimat wilayah Kabupaten Tasikmalaya yang sangat cocok untuk budidaya tanaman manggis, terlihat dari klasifikasi kesesuaian iklim yang ditampilkan pada Tabel 5.

Tabel. 3. Nilai Potensi Poduksi berdasarkan Iklim (CPP) dan Potensi Produksi berdasarkan Manajemen dan pengelolaan lahan (LPP) Manggis per bulan pada daerah Kab.50 Kota

\begin{tabular}{ccccccc}
\hline Sampel & $\begin{array}{c}\text { Produksi } \\
\text { sebenarnya } \\
\text { (Ton/Ha) }\end{array}$ & $\begin{array}{c}\text { RPP } \\
\text { (Ton/Ha) }\end{array}$ & $\begin{array}{c}\text { CPP } \\
(\text { Ton/Ha })\end{array}$ & $\begin{array}{c}\text { Indeks } \\
\text { Manajemen } \\
(\mathrm{My})\end{array}$ & $\begin{array}{c}\text { Indeks } \\
\text { Tanah } \\
(\text { Sy })\end{array}$ & $\begin{array}{c}\text { LPP } \\
(\text { Ton/ha })\end{array}$ \\
\hline I & 5 & 9.90 & 18 & 0,67 & 0,5 & 6.03 \\
II & 12 & 10.56 & 19 & 0.82 & 1 & 15.58 \\
III & 5.5 & 9.49 & 18 & 0.92 & 0.47 & 7.78 \\
IV & 4 & 10.04 & 19 & 0.47 & 0.5 & 4.46 \\
V & 5 & 10.24 & 19 & 0.4 & 1 & 7.6 \\
VI & 3 & 9.24 & 17 & 0.5 & 0.38 & 3.23 \\
\hline
\end{tabular}

Tabel. 4. Nilai Potensi Poduksi berdasarkan Iklim (CPP) dan Potensi Produksi berdasarkan Manajemen dan pengelolaan lahan (LPP) Manggis per tahun pada daerah Kab.50 Kota

\begin{tabular}{ccccccc}
\hline Sampel & $\begin{array}{c}\text { Produksi } \\
\text { sebenarnya } \\
\text { (Ton/Ha) }\end{array}$ & $\begin{array}{c}\text { RPP } \\
\text { (Ton/Ha) }\end{array}$ & $\begin{array}{c}\text { CPP } \\
(\text { Ton/Ha) }\end{array}$ & $\begin{array}{c}\text { Indeks } \\
\text { Manajemen } \\
\text { (My) }\end{array}$ & $\begin{array}{c}\text { Indeks } \\
\text { Tanah } \\
(\text { Sy })\end{array}$ & $\begin{array}{c}\text { LPP } \\
(\text { Ton/ha })\end{array}$ \\
\hline I & 60 & 118.8 & 216 & 0.67 & 0.5 & 72.36 \\
II & 144 & 126.72 & 228 & 0.82 & 1 & 186.96 \\
III & 66 & 113.88 & 216 & 0.92 & 0.47 & 93.39 \\
IV & 48 & 120.48 & 228 & 0.47 & 0.5 & 53.58 \\
V & 60 & 122.88 & 228 & 0.4 & 1 & 91.2 \\
VI & 36 & 110.88 & 204 & 0.5 & 0.38 & 38.76 \\
\hline
\end{tabular}


Hubungan Kondisi Fisik Lahan dengan Kesuburan Tanah dan Produksi Manggis

Kondisi lahan yang perlu dipertimbangkan dalam menentukan sistem produksi adalah topografi dan tanah, salah satu unsur dari topografi adalah lereng. Lereng yang terjal akan membatasi pemakaian mesin pertanian sehingga diperlukan tenaga manusia yang lebih banyak untuk memberikan masukan ke lahan dan membawa hasil pertanian keluar ke konsumen.

Bentuk lahan pada lokasi penelitian merupakan tipe fisiografi dengan topografi datar dan bergelombang. Menurut Desaunettes (1977) kelerengan yang tinggi menyebabkan aliran permukaan dan erosi yang besar. Sehingga atas dasar pertimbangan resiko, lahan ini secara umum tidak dianjurkan untuk dibuka sebagai lahan pertanian. Lahan dengan lereng antara $16-45 \%$ hanya dianjurkan untuk tanaman permanen seperti perkebunan tanaman keras dan kehutanan. Sedangkan lahan dengan lereng $>60 \%$ dibiarkan hutan.

Batuan induk dan bentuk wilayah mempengaruhi proses pembentukan tanah di lokasi penelitian, dengan demikian juga akan mempengaruhi kesuburan tanahnya. Selanjutnya berdasarkan hasil pengamatan di lapangan tanah di lokasi penelitian mempunyai tekstur liat, masam, kandungan hara dan kation basa, kandungan bahan organik dan KTK tanah dapat dilihat pada Tabel 6.

Tabel 5. Klasifikasi kesesuaian iklim untuk Tanaman Manggis di daerah Kab.50 Kota

\begin{tabular}{|c|c|c|c|c|c|c|}
\hline $\mathrm{Sim}$ & Parameter iklim & Nilai & Kelas & Level limit & Rating & \\
\hline$\overline{\mathrm{C}}$ & Curah hujan (mm) & 2238.7730 & S1 & 0 & 100 & \\
\hline $\mathrm{C}$ & Suhu Rata-rata & 26.7525 & $\mathrm{~S} 1$ & 0 & 100 & \\
\hline $\mathrm{C}$ & Suhu maksimum & 33.2708 & $\mathrm{~S} 1$ & 0 & 100 & \\
\hline $\mathrm{C}$ & Suhu minimum & 20.1898 & S1 & 0 & 100 & \\
\hline \multirow[t]{3}{*}{ C } & $\mathrm{n} / \mathrm{N}$ & 97.6686 & S1 & 1 & 85 & \\
\hline & $\begin{array}{l}\text { Indeks Iklim } \\
\text { Rating Iklim }\end{array}$ & & $\begin{array}{l}\text { Method } \\
\text { Method }\end{array}$ & $\begin{array}{l}\text { Root Method } \\
\text { Root Method }\end{array}$ & & $\begin{array}{l}75 / 78 \\
85 / 92\end{array}$ \\
\hline & Kelas Iklim & & & $\mathrm{S} 1 /$ & & S1 \\
\hline
\end{tabular}

Tabel 6. Kandungan hara tanah yang diambil pada Kec. Guguk dan Payakumbuh pada kedalaman 0-60 cm

\begin{tabular}{lclll}
\hline Sifat kimia tanah & Guguk & Payakumbuh * \\
\hline $\mathrm{pH}$ & 4.90 & $\mathrm{~m}$ & 5.3 & $\mathrm{~m}$ \\
C-organik $(\%)$ & 1.98 & $\mathrm{r}$ & 2.50 & $\mathrm{~s}$ \\
N-total $(\%)$ & 0.12 & $\mathrm{r}$ & 0.27 & $\mathrm{~s}$ \\
P-tersedia $(\mathrm{ppm})$ & 55.67 & $\mathrm{t}$ & 48.50 & $\mathrm{t}$ \\
$\mathrm{KTK}(\mathrm{me} / 100 \mathrm{~g})$ & 8.12 & $\mathrm{r}$ & 9.67 & $\mathrm{r}$ \\
$\mathrm{KB}(\%)$ & 39.55 & $\mathrm{~s}$ & 40.86 & $\mathrm{~s}$ \\
$\mathrm{~K}(\mathrm{me} / 100 \mathrm{~g})$ & 2.01 & $\mathrm{st}$ & 1.75 & $\mathrm{st}$ \\
$\mathrm{Na}(\mathrm{me} / 100 \mathrm{~g})$ & 2.69 & $\mathrm{st}$ & 2.41 & $\mathrm{st}$ \\
$\mathrm{Ca}(\mathrm{me} / 100 \mathrm{~g})$ & 26.02 & $\mathrm{st}$ & 29.99 & $\mathrm{st}$ \\
$\mathrm{Mg}(\mathrm{me} / 100 \mathrm{~g})$ & 8.83 & $\mathrm{st}$ & 6.71 & $\mathrm{t}$ \\
$* \mathrm{~m}=$ masam, $\mathrm{sr}=$ sangat rendah, $\mathrm{r}=$ rendah, $\mathrm{s}=$ sedang, $\mathrm{t}=$ tinggi, st = sangat tinggi
\end{tabular}

$* \mathrm{~m}=$ masam, $\mathrm{sr}=$ sangat rendah, $\mathrm{r}=$ rendah, $\mathrm{s}=$ sedang, $\mathrm{t}=$ tinggi, $\mathrm{st}=$ sangat tinggi 
Berdasarkan data yang ditampilkan pada Tabel 5. perbedaan sifat kimia tanah akibat perbedaan ketinggian tempat dicirikan oleh hasil analisis mempunyai kisaran yang sama yaitu $\mathrm{pH}$ tanah masam, kandungan C-organik rendah- sedang, Ntotal rendah-sedang, KTK rendah.

\section{KESIMPULAN DAN SARAN}

Secara fisiografis dan iklim daerah Kab.50 Kota sangat sesuai untuk pengembangan tanaman manggis. Tingkat kesesuaian iklim adalah pada kelas S1 (Sangat sesuai), dengan potensi produksi 312 ton/ha/tahun dapat ditingkatkan menjadi $>15$ ton/ha/tahun bila manajemen pengelolaan lahannya diperbaki. Faktor penunjang untuk peningkatan produksi manggis adalah membuat kebun manggis secara monokulutr dengan mengoptimalkan pemanfaatan lahan terlantar yang cocok dengan agroklimat komoditas manggis, disamping itu diperlukan penguatan modal petani dan mengundang investor.

\section{DAFTAR PUSTAKA}

FAO. 1976. A Framework for Land Evaluation. Soil Buletin No.29. Rome. 72 pp.

Fiantis, D. 2001. Pengembangan Sistem Informasi Geografi Tanah Vulkanis Sumatera Barat untuk Peningkatan Produksi Tanaman Hortikultura. Proposal Riset Unggulan Terpadu IX. Universitas Andalas. Padang. $13 \mathrm{Hal}$.

Gandasasmita, K dan N. Kusumo. 1999. Pemanfaatan Sistem Informasi Geografi Tanah untuk Delineasi Zona Agroekologi. Prosiding
Kongres Nasional VII HITI. Pemanfaatan Sumberdaya Tanah sesuai dengan potensinya menuju keseimbangan lingkungan hidup dalam rangka meningkatkan kesejahteraan rakyat. Himpunan Ilmu Tanah Indonesia. Bandung 24 November 1999. Hal 1311 1321.

Prahasta, E. 2001. Konsep-konsep Dasar Sistem Informasi Geografis. Informatika. Bandung 297 Hal.

Rossiter, D. 1995. Automated Land Evaluation System. Internal Lecture in Center for Soil and Agroclimate Research Bogor. Unpublished.

Suwandana, E dan Turmudi. 1995. Penentuan Lokasi Keramba Apung untuk Budidaya Tiram Mutiara (Pinetada maxima) dan Rakap Putih (Lates calcalifer) dengan Teknik Penginderaan Jauh dan SIG di Teluk Kupang dan Pulau Semau Nusa Tenggara Timur. Pertemuan Ilmiah Tahunan Mapin. Institut Teknologi Surabaya. Surabaya.

Sys, C., E. Van Ranst and J. Debaveye.1991. Land Evaluation Part I. Principles in Land Evaluation and Crop Production Calculations. ITC for Post Graduate Soil Scientist State University of Ghent Bhergium.

Van der zee, E. 1996. sdple. Draft Technical Report. LREP II/Part C LSAR-EURO Consults. 